\section{THE HARVEIAN ORATION.}

Delivered at the Royal College of Physicians, October 18th, $188 \%$.

Br WILliaM H. STONE, M.A., M.B., F.R.C.P., F.R.C.S.E., Physician to, and Lecturer on Natural Philosophy and Materia Modica at, St. Thomas's Hospital.

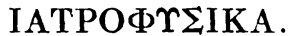

Nothing would have better pleased me, Mr. President and brother Fellows, than to have revived the ancient and time-honoured custom of a Latin oration, such as these walls have so often echoed to ; and this the more gladly from my belief that the practice tended to maintain the dignity of our College, and its reputation for learning. But there is a tide in popular opinion which seems just now to be setting somewhat strongly in a direction opposite to the older and traditional cultivation, and a prepossession abroad that a knowledge of the ancient tongues ou which our English langaage is founded is incompatible with ability to search out the secrets of Nature by way of experiment.

A striking refutation of the fallacy exists in the very man whom and whose labours we are met here to-day to commemorate, and whose honoured name as written in Latin by his own hand should stand in the forefront of my discourse as it does on the titlepage of the manuscript :

\section{GULIELMUS HARVEIUS.}

I say in his own hand for, thanks mainly to the energy and labours of Sir E. Sieveking, we have now before us a noble production of his manuscript lectures delivered in 1616 ; not merely the avtos $\epsilon \iota \pi \epsilon \nu$, but the avtos $\epsilon \gamma \rho \alpha \psi \epsilon$, the vory autograpb "sign manual of a great mind, wherein we can read not only his verbal utterances, but can, with a little care at the same time, trace character, education, and temperament. It is just ten years since the gentleman named above announced to the College the rediscovery of the first Harveian lectures, and now the autotype copy with its transcript is fully before us.

My object therefore on the present oscasion will be to endeavour briefly to comment on this most interesting and unique work, and to sketch the lineaments of Harvey, self-revealed, as a scholar, a lecturer, a physicist, and as a man of genial, not to say humorous, disposition.

In so doing we may gather from the ipsissima verba of one who "being dead yet speaketh"- two lessons, which I believe have not occupied the attention of my many far abler predecessors in this chair.

First, an instruction in the art and method of lecturing, and wherein in this age of printed books it may still be of service.

Secondly, what a large field of discovery and research still lies open to us, as it did to Harvey, on the borderground betwe nn physics and physiological medicine. For this reason I have ventured to give my

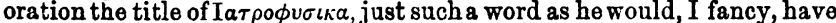
delighted to jot down, possibly in red ink with his cypher appended, in some corner of his manuscript notes. For the discovery wbich has rendered Harvey's name famous was strictly physical, I may even say mechanical. It had, moreover, one great element of accuracy in applied mechanics; it was computational and quantitative.

There can be little doubt that general ideas were abroad on the subject of the circulation, and that similar views, not indeed incorrect, but loose and inaccurate, had been entertained by others. Even Cresalpinus, pace Dr. George Johnson, undeniably had glimpses of the truth. It was, however, Harvey who first saw and proved that the problem was one of hydrostaties, and that it must be solved and could be solved by mechanics, and proved by numerical relations.

There is a remarkable page in the lectures, one of the best written and most legible in the book, in which this is stated with absclute clearness, and which at once disposes of any claims advanced in other quarters. It runs as follows :

"Constat per fabricam cordis sanguinem per pulmones in Aortam perpetuo transferri, as by two clacks of a water bellows to rayse water. Constat per ligaturam transitum sanguinis ab arterijs ad venas, unde $\Delta$ perpetuum sanguinis motum in circulo fieri pulsu cordis."

The two hydrostatic conditions of the circulation are herein defined with geometrical accuracy, and read like the enunciation of a theorem in Euclid. Indeed, it is remarkable what a strong mathematical element runs through the argument of both his great treatise and of [1399] the lectures ; not, of course, mathematics as we now understand them, for at the date of Harvey's death Newton was a boy of 15, but those of Eaclid and of Archimedes. In the second page of the MS. work he speaks of form "ut trigonis in tetragonum," of proportion "ut diapente in diapason, the relation of tho triangle to the square, of the fifth in music to the octave. An even more remarkable reference to musical ratios occurs a fow lines later, "ut semiditonus diapaso," like a semitone to an octave.

Again in the ninth page we find "Proportio pectoris ad ventrem diatessaron ut 3.4 sesquitertia; pectoris ad caput ${ }_{3}^{2}$ diapente, pectoris ad alvam 2 diapason; both these last two ratios being expressed as fractions.

We have, moreover, direct personal evidence to his studies in this direction; for Aubrey found him reading Onghtred's Clavis Mathematica, and working the probloms when he was no longer a young man. Now his strongest and most irrefragable argument for the new view of the circulation is distinctly numerical. "Supponamus," he says, "quantum sanguinis sinister ventriculus in dilatione quum repletas says, "quantum sanguinis sinister ventriculus in dilatione quum repletus further on the problem thus concisely proposed is continued :

"Its in homine protrudi singulis cordis pulsibus supponamus unciam semis, vel drachmas iij, vel drachmæm unam sanguinis, qui propter impedimentum valvularum in cor remeare non potest. Cor unâ semihor̂̂ plus quam mille pulsus facit. Jam multiplicatis drachmis videbis unâ semihoîa, aut millies drachmas tres, vel drachmas duas ant uncias quinquios centum, per cor in arterias transfusum, quæ major est copia quam in universo corpore contingat reperiri. Quare concludendum si unciam transmissam contingere, libras 83 et そ̧iv in unâ semihor $\hat{a}$ transfusas esse de venis in arterias."

$\mathrm{He}$ saw distinctly that the heart was simply a double force-pump, propelling an incompressible fluid into an equally double system of tubes; that it was the sole efficient cause of the motion thus engendered (indeed, he uses the phrase, "solum a corde"); that the lungs, althongh an air-pump of no inconsiderable power, both for compression and rarefaction, had nothing whatever to do with this; that the valves of the heart acted equally as machines to make good the dynamical advantage thus obtained, and that the quantity of fluid thus raised was incomparably greater than had been before supposed. The cunception is as distinctly mechanical as that of the steam engine, or of the mechanical equivalent of heat which were to arise in later centuries. Even of this last great generalisation in mechanics, he had no indistinct glimpse, for in the thirteenth page of the MS. he compares heat to a hammer. "Calor ut malleus instrumentum instrumentornm." With the working out of this complex but perfectly precise problem in hydrodynamics, came accuracy and certainty in place of theory and conjecture. "Flux and reflux" had had their day, and no more need be said of that unlucky Euripus which is fabled to have driven a great natural philosopher, Aristotle, to suicide, and which had been an incubus on science ever since.

Only twenty-six short years after the first Harveian lectures were committed to paper, and fourteen after the treatise De Motu Sanguinis appeared, the wondrous boy was born who was destined in like manner to penetrate another of Nature's mechanical mysteries, the problem of universal gravitation. Newton was 15 years old when Harvey died, and already studying Oughtred's Clavis Mathematica, the very work which Aubrey found Harvey engaged upon, as above stated.

As regards Harvey's classical scholarship, little needs to be added to what has already been well said. The scholar of Canterbury Grammar School and the pensioner of Caius College, Cambrijge, was clearly well trained in classics, dialectics, and physics. He evidently knew Aristotle thoroughly, and often quotes him, especially the grand treatise on Metaphysics, and the excellent book on the Ceneration of Animals, a quotation from which stands on the title-sheet of the lectures. For it must be remembered in these days of detraction, that Aristotle was no mean naturalist, and even comparative anatomist ; many of his shrewd observations in this direction being sound even to the present time. "Naturæ diligentissimus investigator," are the words. Harvey also quotes the Gorgias of Plato; and there is a passage in the preface to his treatise $D_{i}$ Generatione which so completely recalls the myth of the cave in Plato's Republic, that it camnot be an accidental coincidence. "Hi," says he, "non veras ideas, sed falsa idola et phantasmata inania mente concipiunt; unde umbras quasdem et chimæras sibi fingunt." It is difficult also to believe that this metaphor had not been recalled to Harvey's memory by the use of it under the name of Eidola Specus, in a great work then recently produced, which overtly in its very title professed to be an extension of Aristotle's grand work on formal logic ; namely, the Novrum Organon of Bacon. 
Aubrey says, in his Lives of Eminont Persons, that he understood Grook and Latin pretty well, bat was no critic, and wrote very bad Istin. We are, however, nor in a position to judge of this for oursolves from the real autograph. The Greek words scattered freely throngh the lectures are well written and spelt, though in one or more instances the first part of a word begins in Greek and finishes in English chsracters. Bit this is only on a par with the whole work, which is a cento of Greek, Latin and English, never intended to be 8aen by any oyo besides that of the writer himself. Yet oven thus in paseases they rise almost to eloquence, 29 in p. 47, where, speaking of the maintenance of human species by generation, in spite of the death of the individual, he says :

"By the striog tyed to eternity. Unde cum naturs non potnit Individualom reternitstem, id quod potuit haram partium facultate peciom mternitatis generando sibi similem in secula. Unde sacris literis greateat blessing Issue, that thy soed shall remayno for ever."

Aind farther on :

"Apparet item maribus ot fominis qui moderate ntuntur never more brar,e, sprightly, blith, valiant, pleasant, or bewtifull."

Which cannot fail to remind us of the passage in the fourth Georgic of his farourite author Virgil :

\section{"Ergo ipsas quamvis angusti terminns ævi}

Excipiat (neyue enim plus septima ducitur æstas)

At ganus immortale manet, multosque per annos

Stat fortuns domus, et avi numerantur atornm."

Rat before lesving the loving commemoration of our great bene. frctor, I wish' to point out some evidences of his genial and even humorous temper, which must have made the lectures pleasant to liaten to.

P. 16. Speating of the position of the abdominal organs, he says : "Situs omnium partim certus partim incertus." Then, breaking into familiar English, he notes : "Natura Romidges (sic) as she can best stow, as in ships." While still on the same topic, he points out that malposition of organs occurs in "yooung (sic) girls by lacing; unde cutt there laces."

P. 53. In another place, in describing an irreducible hernia, he says it may be filled "cnm maximâ quantitate aquæe et flatus." "The man behind Covent Garden - Bıl."

P. 55. The spleon is described in man "ut washous to the kitchin," and its absence in lower organisms, "Inferior kitchins need noe waehhous." Lastly, "in quihus vitiatum temperamentum Lien Mojor, The wash hous exceed je kitchin."

P. 64. It is diff ult to beliere that the passage which follows"Mas a vigore spiritus higher sett, unde Bastards brave men, quis magno fervore geniti vetito concubitu" -is not a reflection of Shakeapeare's bastard, Faulconbridge, a character which Harrey may have eon represented, even by its creator himself, at any time in the eighteen previous years.

P. 50. But perhaps the quaintest entry is one speaking of some rather controvertible anatowical assertions, which he thus records: "W. H., a little staggerum in these."

He describes the thymus gland as follows: "Thimus, sweete bread, nutt of veal-, corpits glandosum molle, heare they sticke the pigg." And a littlo farther on, speaking of some idle controversy of previous writers, he describes it "est de lanî capriâ" which is obviously a note jotted down from the Horatian line, "Alter rixatur de lanâ expe caprinâ" In an excellent account of the signs of asphyxia, he says: "Sos curst children by eager crying grow black and suff, cated, non deficiente animali facultate," which again recalls to our memory Kate the Curst in the Taming of the Sirrew.

There is, however, one page of this remarkable volume which requires $m$ ire than cursory notice, as beyond illustrating the character of our distinguished benofactor, which I am specially directed to do, it affurds us trom his example a valusble lesson for our own instruction. These are the Canones Anatomiæ Generalis, rules which he evidently laid down to himself, and in which he has left us a precions legacy of a trice. They are twelve in number, hastily, but evidently afrer mature thought, jofted down in the strange mixture of Latin and English which is throughout the book adopted (p. 4). Canones Anatomix generalis

1 hew as much vno intuitu as can be t de toto ventre : vel toto aliquo quæ accidunt deindo diridere (propter situs ot coneziones

2 demonstrare propria illius Cadareris Nova vel Noviter inventa

3 to supply only by speech what cannot be shewn on your own credit and by authotity
4 cutt vp as much as may be in presentiâ at cum Historît peritia innotoscat

5 observationes proprias et alienas recensere ad confirmandam propriam opinionem vel obsignatis tabulis in alijs Animalibus agere

secundum Socratis regulam : where it is farer written vnde observationes exoticas

( 1 ob causas MIorborum: Medicis præcipue vtilissimas

2 ob varietatem Naturæ philosophica

3 ad refutandos errores et proinde solvendos

4 ob vsus et actiones Inveniendas dignitates et propter inde Colectanea

Anatomia enim finis partis Cognitio propter quid

Necessitas et vsus

philosophis precipue qui inde sciunt

ad vnamquamque actiones qua requiruntur quod præstat

Medicis item qui inde constitutionem naturalem

regula quo diducendi ægrotantes

et inde quid agendum morbis

6 Not to prayse or disprayse. all did well

and behowlding ijs qui perperam quia occasio

7 Not to dispute confute alias quam argumentis ostensis quia plus quam iij dies requiruntur

8 Brefly and playnly : yett not letting pas any one thing vnspoken of which is subiect to the vew

10 Not to speake anything which with outt the carcase may be delivered or read at home

11 Non nimium curiose pertinet enim particularibus dissectionibus et tempus non patitur

12 to serve in their iij courses according to the glass

$\int 1^{\circ}$ ventris inferni nasty yett recompensed by "admiry" admirable variety

( $2^{\circ}$ the parlor $3^{\circ}$ divine Banquet of the brayne

It is singular how much of this is still valuable, though written at a time when printed books were scarce, oral lectures the chief mode of teaching, and primcrs, text-books, compendia, with all the artillery of cram, unknown. Indeed, a direct answer is given to the paradox which has of late obtained some rogue, and which has been fostered by examining machines miscalled universities, that lectures are useless, and that it is only nocessary to ascertain that a student knows certain prescribed facts without asking how and where he learned them. Those of us who are teachers and examiners (and I am aware I am speaking before the most learned body of teachers and examiners in this kingdom) know the fallacy : it is a fallacy, moreover, chiefly in the higher branches of thought, where absolute certainty is unobtainable, and where tact, experience, and the exercise of a judicial function of the mind are necessary. It is a fallacy still more where acutely cultivated senso-the memory of the eye, of the ear, and of the touch-have to be added to these characters.

As an examiner myself to this College of over seven years' standing, I feel I can often detect book knowledge and perrot.like iteration of catch-words learned by rote but not thought out in some voluble but superficial candidate. Indeed, Charles Dickens and Albert Smith (the latter a medical student himself, both acute observers of human nature) have each pilloried flagrant offenders in this direction with the severity and incisiveness of real humour. To these book-read ans. tomists and school-board paradoxists an admirable answer is given in the words, "Cutt $\nabla p$ as much as may be in presentîi, ut cum Historiâ peritia innotescat." That, with the descriptiou, practical ex. perience should arise.

But it is not only the superficial and sciolistic learner who may gather lessons from this remarkable page; there is much that we as locturers and teachers may take to heart with advantage. "To supplye only by speech what cannot be shown on your own credit and by authority :" also, "observationes proprias et alienas recensere, ad confirmandam propriam opinionem."

There is often, even at the present day, much difficulty in the fall performance of the duty here so lucidly and tersely set forth-that, namely, of comparing our own with other observations. It occurs to a great extent in the department to which the present speaker's chief attention has been devoted, that, namely, of physics. Much valuable work and informaticn are stored away in papers read before learned societies, in small detached pamphlots, in foreign and scientific periodicals, and similar places very hard to reach for purposes of consultation. Hence follows no little repetition of labour in rediscovery, and the consequent disappointment of perfectly conscientions obserrers who have unwittingly gone over the same ground as their forernnnerg in science. It is, moreover, from comparison of one's own views with 
those of previous labourers, if it be performed in a conscientious and thorough manner, that new views and ideas often arise.

It is not, however, so much in the seeking out of new facts in Nature that these Canones help us, as in suggestions for the communication of knowledge, a function especislly important in the art of medicine, because at the end of our educational chain there hangs suspended a human life. There can be no hesitation in calling this pregnant eollection of maxims a treatise on the art of imparting knowledge; an art too much neglected even in the present age. For, sooth to say, Englishmen fall, I fear, somewhat behind their French and German rivals in the practice of this important function. Even their speech and articulation are often inferior, as anyone who has listened to Troussean, Clande Bernard, or Virchow, must be well aware. "Brefly and playnly: yett not letting pas any one thing vnspoken of, which is subiect to the rew," says our thoughtful monitor. Then again, "Not to dispute slias quam argumentis," a quiet sarcasm on obtrusive controversialism which may go home to many a pulpit beyond this from which I have the honour to address you.

We are now in a position to gather in the fruit of our anthor's teaching; and first as to the ntility of lecturing. We have it in his quaint language that it is justly a combination of what a book can givo-namely, knowledgo-with what it cannot, namely, intuitus or demonstration. In many subjects, in none certainly more than general anatomy, this is a point of no mesn importance. The eye can assist the ear ; two inlets are afforded at once to the sentiont brain instead of one, and two forms of memory can be called forth. For it is a fact, though one soldom insisted on, that memory has at least as many forms as there are senses. The memory of the car is perhaps the commonest but a'so the least intellectual, unless applied to harmonious sounds and melodies. Unfortunately, the mere reproduction of the dry husks of thought termed words is too much cultivated in these days of overpressure, and too little care is t3ken to secure the essential nucleus of the grain of thought. To the anatomist, the surgeon, and the man of science generally, the memory of the eye trans. cends the former. A geometrical memory, which can reproduce forms healthy or diseased, is an acquirement especially to be cultivated by the student of medicine and pathology. This is far better done in lectures than by books.

Secondly, the lecturer can keep himself abreast of all things "Nova vel Noviter inventa," whereas the book, even if at first up to date, as it seldom is, soon falls back in the race and becomes ancient. There are, indeed, books like the Metaphysics of Aristotle, the Republic of Plato, and the Aphorisms of Hippocrates; more lately the Principia of Newton, the Religio Medici of Sir Thomas Browne, and the work De Sedibus ct Causis Morborum, by Morgagni, which will never grow old; but when we come to the new philosophy, and wrest daily fresh secrets from Nature, the case is different. Here also the lecture far transcends the book; especially if the lecturer, standing on the brink of the precipice which separates the known from the unknown, can detail facts or deductions which he can vouch for and prove "on his own credit and authority," as saith our teacher. It is a severe labour indeed, but a labour of love in these days of scientific progress, to keep oneself informed of all fresh truths as they arise, so as to impart them "brefly and playnly" to younger and still thirsty minds. If to these he can add "observationes proprias," original facts and investigations, the lecture reaches a pitch of individual interest which none but the greatest books, certainly no handbooks or manuals, can ever attain.

Lastly, the lecture, well clelivered, has a greater point and flexibility than the written volume. The lecturer, like the actor, can study his audience, and wake their attention by a judicious or even humorous allusion. The manuscript before us teems with these, indeed several have been already cited ; perhaps, however, the quaintest of all occurs in the description of the diaphragm. After giving its function as a septum or partition, he mentions the old English name midrefo, and this he compares to the shere or shire reva or reeve, a well known connty officer at the time, and says, "his office serving to both belly and lungs he is stickler between them." There cen be little doubt that a smile passed over the grave countenances of the assembled physicians at this homely allusion.

Thus did the first Harveian lecturer, as we see from the veriest editio princeps possible of the first lectures, fulfil the precept to "make these dry bones live," to give the vivifying force of character, fancy, and originality to the general facts of anstomy. Since then 271 years have run their course, and still the sacred fire of thought and gonius burns in them undimmed by time.

There yet remains one part, perhaps the most important, of my prescribed task to be purformed, and that is to draw a practical conclusion from the essentially physical and mechanical character of
Harrey's great discovery. That he himself fully know this has been already shown in his own words, and also bp his division of anstomy into three part3, Philosophica, Medica, and Mechnnica. Now at the presont time investigation and research are abundantly carried on in the pathological, physiological, and therapeutical aspects of medicine, but the physical or mechanical side is somewhat neglected. For hundreds of ardent questioners of Nature, who are labouring with the microscope, in the biological and the bacteriological laboratories, those who attack medicine from its physical side, may be counted on the fingers of one hand. Nor indeed are the written treatises on this subject abundent, in this country at least. The Animal Mechanics, of the Rev. Dr. Haughton, of Trinity Collerge, Dublin, is an exceptional work of great value, which has hardly received the attention it deserves from the medical profession, but it stands almost alone as the representative of its class. On the Continent, however, and in Aneric the case is very different. The admirable Afedical Physics of l'rofessor Wundt, of Ileidelberg, has bee $n$ translated from the German into French, with valuable additions by Dr. Ferdinand Monayer, who regularly lectures on medical physics at the Lyons Faculty of Medicine, and atfords a storehouse of information of the highest value to the medical practitioner.

Dr. John C. Draper, Profassor of Chemistry and Physics in the Medical Department of the University of New York, has also made valuable contribution to the literaturo of this subject in his Textbook of Arcdical Physics, published the year before last. There is, indeed, a small but scanty manual by Dr. McGregor Robertson, the Muirhead Domonstrator of Physiology in the University of Glasgow, published in Cassell's Student's Series, but it is entirely unfit to compete with the two exhaugtive treatises named before.

As with the bibliography, so with the teaching. With the exception of a course of lectures which the present speaker has delivered since 1871 in St. Thomas's Hospital, I am not aware of any systematic attempt in London to teach the medical student the vast mass of pliysical facts which underlie the daily practice of medicine. This College, however, forms an honourable exception, for it has on two occasions kindly given me the opportunity to bring before my brother physicians some few of what our Harvey terms "Nova vel Noviter inventa"-respecting the Physical Basis of Aluscultation in the Croonian, and the Electrical Conditions of the Human Body in the Lumleian, lectures of a fow years back.

It is true that the University of London, in its Preliminary Scientific Examination for the degree of Bachelor of Medicine, requires students to satisfy their examiners in physics by means of a written paper. But this paper is the same as that set to Bachelors of Science not medical. It is a terrible stumbling block to the rising medical generation; it bristles with what the late genial Professor De Morgan, himself a mathematician of the highest order, delighted to call mathematical conundrums ; it is set by pure physicists, who know nothing, and probably care little, for the problems which interest us as medical men. It contributes a large percentage to the slaughter of innocent aspirants to the higher degrees in medicine, on which one of their most distinguishod graduates, now Censor of this College, has feel. ingly and righteously commented. In the sixteen years during which I have carefully read the papers there set, I have never once seen a question directly or indirectly bearing on the physics of medicine.

The fact is that the large, difficult, and somewhat heterogeneous branch of knowledge connoted by the word physics is rapidly splitting into severel independent portions. There are now distinctly mole. cular, mathematical, industrial, and physiological physics. It is the last of these with which we are concerned. The third or industrial branch has been enormously developed of late by the technical colleges at Bristol, Manchester, in the City guilds, at Kensington, and elsewhere. The mathematical branch is well cared for by the two old Universities of Oxford and Cambridge, but the physiological section has been hitherto hardly enough recognised by our teaching bodies. Surely an earnest student should be sble somewhere to obtain information as to the natural laws on which the stethoscope, the microscope, the oph. thalmoscope, and the sphygmograph are founded, without having to wade through interminable problems on the C. G. S. system of unita, or vortex theories of matter, or-chimers of chimeras-the possibility and advantages of four-dimensional space.

It is to the promotion of this particular branch of study by means of experiment that it is this day my duty to exhort the College. An admirable opportunity exists, for in April of the present year the Committee of Delegates appointed by this College and the Royal College of Surgeons of England reported;

1. That it is desirable to utilise the vacant ground adjoining the Examination Hall for scientific purposes, under the control and management of the two Colleges. 
2. That the "scientific purposes" be, in the first place, the investigation and exposition of such branches of science connected with medicine and surgery as the two Colleges may from time to time determine.

The College has subsequently adopted the report.

Now, I submit with the utmost respect, but with the greatest earnestness, to those here assembled, that a course of physiological physics, to be delivered in the new college of science, would be a real boon to all students of medicine, whether they had succeeded in obtaining their diploma or not. The human body is a mass or congeries of separate machines, susceptible of mechanical explanation; but, setting aside the heart and lungs, already named, how many students have their attention specially drawn to Donders's and Landolt's optical researches on the eye and eyesight, or to Helmholtz's account of the mechanism of the ear? Such a course, moreover, would in no way clash with other courses given elsewhere on different branches of the same great subject, and it would eminently fulfil the exact purpose, even to the very words, of the great man whom we are to-day met to commemorate.

\section{AN ADDRESS}

\author{
ox
}

\section{THE PSYCHOLOGY OF JOKING.}

Delivered at the Opening of the Medical Society of London, October, 188\%.

Bx J. HUGHLINGS JACKSON, M.D., F.R.C.P., LL.D., F.R.S.,

Physician to the Hospital for Epilepsy and Paralysis; and Physician to the London Hospital.

AFTER some preliminary remarks, Dr. Hughlings Jackson said : I think punning does not receive enough attention. In spite of Dr. Johnson's well-known dictum, we should not despise punning. Sydney Smith says that it is the foundation of all wit. Supposing three degrees of evolution, I submit that (1) punning is the least evolved system of joking, that (2) wit is evolved out of punning, and that (3) hamour is evolved out of wit. Everybody has heard of Sydney Smith's remark-that it requires a surgical operation to get a joke into the head of a Scotchman. But he spoke without distinguishing. The Scotch have a great appreciation of those highly evolved jocosities displaying the humorous, although, no doubt, a scorn of simple, lowly evolved jocosities, such as plays on words. It is difficult to form a conception of a Scotch Punster; yet I have heard an Aberdonian, a physician of world-wide reputation, make a pun.

Punning is well worthy of the Psychologist's attention. I seriously mean that the analysis of puns is a simple way of beginning the methodical analysis of the process of normal and abnormal Mentation. This, I think, I can easily show.

Vision is stereoscopic; in a sense it is slightly diplopic, for there are two dissimilar images, although there seems to be but one external object, as we call it. To borrow the ophthalmological term, we can say that Mentation is "stereoscopic ;" always subject-object, although we often speak of it as single ("states of consciousness," etc.). Just as there is visual diplopia so there is "mental diplopia," or, as it is commonly called, "double consciousness."

Now I come back to punning. We all have "mental diplopia" when hearing the answer to a riddle which depends on a pun-" When is a.little girl not a little girl ?" Answer : "When she is a little horse (hoarse) " The feeble amusement we have in the slightly morbid mental state thus induced is from the incongruous elements of a "mental diplopia." The word "hoarse" rouses in us the idea of a little girl who has taken cold, and the same sounding word "horse" rouses in us the idea of a well-known quadruped at the same time. We have the sensation of complete resemblance with the sense of vast difference. Here is, I submit, a caricature of the normal process of all mentation. The process of all thought is "stereoscopic" or "diplopic," being the tracing of relations of resemblance and difference.

To call punning a slightly morbid mental state may be taken as a small joke. But I do not think it very extravagant to describe it so ; it certainly is not if it be a caricature of normal mentation. A miser has been defined as an amateur pauper; the habitual drunkard is certainly an amateur lunatic. And in the same style of speaking we may say that-well, we will say that punning is playing at being foolish; it is only morbid in that slender sense.
The word "play" carries us on in a slightly different direction. Jocosities of all degrees of evolution (1) puns ; (2) witticisms ; and (3) humorous statements are the " play of mind,"-play in the sense in which the word has been used in the remark that the "æsthetic sentiments originate from the play impulse." A further definition of play, as thus used, is given in the following quotation from Spencer:"The activities we call play are united with esthetic activities, by the trait that neither subserve, in any direct way, the processes conducive to life" (Prin. Psych., vol. ii, p. 627). There would be a reat intellectual advance-due, I presume, to Internal Evolutionwhen man began to value things for their beauty apart from their use : one sign of his having "got above" his mere animal self. For it showed that, over and above mind required for mere animal existence, he had some surplus mind for greater ends of life. So I contend that our race owes some respect to the first Punster. For the dawn of a sense of the merely ridiculous, as in punning and simplest jokes, shows the same thing as the dawn of æsthetic feeling-surplus mind, something over and above that required for getting food and for mere animal indulgence. All the more so if punning be that out of which wit and bumour are evolved.

It is not a good sign if a man be deficient in humour, unless he have compensation, as Wordsworth had, in a sense of the sublime, or in great artistic feeling, or in metaphysical subtlety. The man who has no sense of humour, who takes things to be literally as distinct as they superficially appear, does not see fundamental similarities in the midst of great superficial differences, overlooks the transitions between great contrasts. I do not mean because he has no sense of humour, but because he has not the surplus intellect which sense of humour implies. Humour, being the "play" of mind, is tracing deep, fanciful resemblances in things known to be very different. This is "playing" at generalisation, and is only a caricature of the same kind of process which made Goethe declare that a skull is a modified part of a vertebral column.

Now I am about-not really digressing from what I have just said - to say something which sounds very paradoxical : that persons who are deficient in appreciation of jocosities in their degrees of evolution are, in corresponding degrees, deficiently realistic in their scientific conceptions. One would infer this a priori. Every child knowe that a man born blind has no idea of light, but the educated adult knows, too, that the congenitally blind have no notion of darkness. And I think that observation confirms what $a$ priori seems likelythat pari passu with the evolution of the sentiment of jocosity (playing at unreality) is the evolution of power of realistic scientific conception-from sense of the merely ridiculous with parallel realistic conception of simple things up to sense of humour, with parallel realistic conception of complex things. But we must be on our guard not to take commonplace realism about simple things to be realism when applied to very complex things. It seems at first glance more realistic to suppose that sourness is inherent in vinegar than that it is always a sensation in some percipient. But that the former hypothesis is very unrealistic is essily seen when we put such crude metaphysics in other words ; the doctrine then is that part of the taster's own mind is outside himself. It is possible for the same person to be truly realistic in simple things, and to be intensely unrealistic in complex things. Thus, the really practical man, who may tell us that he despises metaphysics, may be crudely metaphysical when he deals with complex things-" "explaining," for example, that a man comatose does not move because he has lost consciousness. Surely the truly realistic conception is that the comatose patient does not move any of his limbs from some physical disability, for essentially the same reason that a hemiplegic man does not move his arm and leg.

I now go back to my small joke that punning is a slightly morbid mental state, a "mental diplopia," a caricature of the normal "diplopia" of healthy mentation. From this point I make the assertion that the "physiological insanity" of dreaming is diplopic-a caricature of that of waking mentation. A physician read in the day of the strained relations of European States; in his dream at night he is called in consultation by Bismarck, and advises a course of the iodide of potassium (directions for the application of the remedy were not given). Clearly, there are here two very dissimilar mental states "pretending" to be stereoscopic; manifestly a seeming fusion of ideas of prescribing for a patient with ideas of the hostile attitude of European States. I hope some time to be able to show that such diplopia has the same kind of mechanism as that of the pun-that the two elaborate dissimilar states are held together by two same, or similar, simple mental states. I go on to remark that in some people there are beliefs as incongruously diplopic as some states in dreams ; diplopic in that way to other people, at any rate. 